\title{
Azotobacter-enriched organic manures to increase nitrogen fixation and crop productivity
}

\author{
M. Ângelo Rodrigues ${ }^{a}$,*, Laurindo Chambula Ladeira ${ }^{b}$, Margarida Arrobas ${ }^{a}$ \\ ${ }^{a}$ Mountain Research Centre - Polytechnic Institute of Bragança, Campus de Santa Apolónia, 5300-253 Bragança, Portugal \\ b Instituto Superior Politécnico do Kwanza-Sul, Angola
}

\section{A R T I C L E I N F O}

\section{Keywords:}

Biofertilizers

Manuring effect

Lactuca sativa

Brassica rapa

Apparent $\mathrm{N}$ recovery

Anion exchange membranes

\begin{abstract}
A B S T R A C T
The use of fertilizers with beneficial microorganisms has increased in recent years. In this study, the performance was assessed of two manures enriched with Azotobacter (BioF1 and BioF2), a non-enriched organic manure (Organ), an inorganic $\mathrm{N}$ fertilizer applied at a rate equivalent to the organic manures (MinR1) and applied at twice the rate (MinR2), and a control treatment. A field trial and a pot experiment were carried out both consisting of a sequence of three crops per year [lettuce (Lactuca sativa)-lettuce-turnip (Brassica rapa)] grown for two years. Above ground dry matter (DM) yield and $\mathrm{N}$ recovery were higher in the inorganic fertilized plots in comparison to the organic manured plots. Anion exchange membranes inserted into the soil in short periods during the growing seasons revealed higher soil nitrate levels in the inorganic fertilized treatments. Organic amendments improved performance over time, proving that their fertilizing effect, though modest in the shortterm, lasts longer. The biofertilizers containing Azotobacter (BioF1, BioF2) increased the bioavailability of $\mathrm{N}$ over Organ, by an additional $\mathrm{N}$-fixing value of $11.4 \mathrm{~kg} \mathrm{ha}^{-1}$ estimated from the six crops of the field experiment ( $\sim 5.7 \mathrm{~kg} \mathrm{~N}$ per year). If compared on the basis of the same amount of $\mathrm{N}$ recovered, organic amendments produced an average increase of $720 \mathrm{~kg} \mathrm{DM} \mathrm{ha}^{-1}$ over the inorganic fertilizer $(\sim 120 \mathrm{~kg}$ per crop) due to a general manuring effect. From the results of these experiments, no beneficial effects on crop growth could be attributed to biofertilizers other than the slight increase in $\mathrm{N}$ fixation.
\end{abstract}

\section{Introduction}

Many microorganisms have the ability to fix atmospheric dinitrogen $\left(\mathrm{N}_{2}\right)$ being collectively known as diazotrophs. Biological reduction of $\mathrm{N}_{2}$ to ammonia is a highly energy-demanding process mediated by nitrogenase, the key enzyme complex which is only present in the microbes capable of fixing atmospheric $\mathrm{N}_{2}$. The ecological importance of biological $\mathrm{N}$ fixation is enormous. General estimates of $\mathrm{N}$ biologically fixed in natural and agricultural ecosystems account for more annual $\mathrm{N}$ input than $\mathrm{N}$ usage as fertilizer (Cooper and Scherer, 2012; Havlin et al., 2014).

Nitrogen-fixing organisms are all prokaryotes (Bacteria and Archaea), belonging to hundreds of species, including aerobic, microaerobic, anaerobic, and photosynthetic bacteria, and actinomycetes (Russelle 2008). In relation to higher plants, they may be symbiotic, associative or free-living. Symbionts are the most significant $\mathrm{N}$ fixers for plants, represented primarily by Rhizobia (Probacteria), Frankia (Actinomycetes) and Nostoc/Anabaena (Cyanobacteria) (Cooper and Scherer, 2012). Nitrogen fixation by Rhizobia depends on the establishment of a symbiotic relationship with leguminous plants. This symbiosis plays the largest role in $\mathrm{N}$ fixation in agriculture, being responsible for about $50 \%$ of total annual biological $\mathrm{N}$ fixation worldwide (Havlin et al., 2014).

Free-living $\mathrm{N}$ fixers can live in soil, water, rhizosphere and leaf surfaces. Some are photoautotrophs depending on light for energy. Heterotrophic $\mathrm{N}$ fixers are another important group of diazotrophs, but they are usually restricted in their fixation capacity by the lack of organic substrates for energy generation (Russelle, 2008; Cooper and Scherer, 2012), resulting in minor benefits to agriculture from their activity. Reported values for such common species as Azotobacter chroococcum are typically less than $0.5 \mathrm{~kg} \mathrm{~N} \mathrm{ha}^{-1} \mathrm{y}^{-1}$ (Smil, 2001).

The importance of beneficial microbes has been increasingly recognized in recent decades and several microbial inoculants have been used in agriculture as a consequence, not only $\mathrm{N}_{2}$-fixing bacteria, but also phosphate solubilizers and phosphate scavengers (Sharma, 2005; Gentili and Jumpponen, 2009). These products are usually known as biofertilizers, which can be defined as substances containing living microorganisms which, when applied to seed, plant surfaces, or soil, colonize the rhizosphere or the interior of the plant promoting growth

\footnotetext{
* Corresponding author.

E-mail address: angelor@ipb.pt (M.Â. Rodrigues).
} 
by increasing the supply of primary nutrients to the host plant (Banerjee et al., 2009).

Among the heterotrophic free-living $\mathrm{N}_{2}$-fixing bacteria, Azotobacter is the most intensively investigated genera. Apart from its ability to fix atmospheric N, Azotobacter is also known to synthesize biologically active growth-promoting substances such as indolacetic acid, gibberellins and B-vitamins in culture media (Sharma, 2005).

In recent decades, inoculants containing $\mathrm{N}_{2}$-fixing and other beneficial microorganisms have been tested on potted plants, nurseries and field crops. However, the use of selected $\mathrm{N}_{2}$-fixing bacteria and arbuscular mycorrhizal fungi alone or in combination have shown slight to moderate benefits in increasing crop productivity and a modest capability to reduce the use of mineral fertilizers (El-Sirafy et al., 2006; Aseri et al., 2008; Gupta and Aggarwal, 2008; Jahan et al., 2013; Ansari et al., 2015). The greater benefits to crop growth seem to occur when an inoculant containing $\mathrm{N}_{2}$-fixing bacteria and other beneficial microorganisms is mixed with organic substrates (Nuruzzaman et al., 2003; Kumar et al., 2007; Singh et al., 2013; Kumar et al., 2014). Kumar et al. (2015) showed that using a biofertilizer in the form of a super granule, containing Azotobacter chroococcum and Bacillus subtilis entrapped in an organic matrix [consisting of cow dung, rice bran, dried powder of neem leaves, and clay soil in 1:1:1:1 ratio and 25\% (w/w) saresh (plant gum of Acacia sp.)], the productivity of wheat was clearly higher when compared with the results of the biofertilizer applied alone.

In Portugal, commercial organic amendments enriched with beneficial microorganisms, in particular of the genus Azotobacter, have recently appeared on the market. From a theoretical point of view, these organic amendments combine inoculum $\left(\mathrm{N}_{2}\right.$-fixing heterotrophic microorganisms) and food supply (organic substrate), thus overcoming the main limitation of fixing $\mathrm{N}$ of the free-living heterotrophic $\mathrm{N}$ fixers, which can increase the potential for biological $\mathrm{N}$ fixation. The weak point in this theory comes from the fact that these microorganisms are ubiquitous in terrestrial ecosystems, that is, under normal conditions they are always present in the soil, and, therefore, the need to apply them with organic fertilizer is questionable. Thus, the major question that arises in this work is whether composted organic amendments enriched with free-living $\mathrm{N}_{2}$-fixing organisms contribute more $\mathrm{N}$ to the plants (through the favourable conditions that are provided to the microorganisms) than composted organic amendments of similar composition but not enriched with such microbes. Additionally, to help assess the performance of the organic amendments, a fertility gradient was created using an inorganic fertilizer applied at the same and double $\mathrm{N}$ rate of the organic amendments.

\section{Material and methods}

This work comprises a field trial and a pot experiment that took place over two years in Bragança, NE Portugal, which included a sequence of six horticultural crops, three per year, namely two springsummer lettuce crops and a turnip crop in the autumn. In the pot experiment, a seventh unfertilized barley crop was also grown to assess the residual effect of the fertilizers applied to the previous crops.

\subsection{Climate and soil}

The climate of the region presents Mediterranean characteristics although with some Atlantic influence. The average monthly temperatures of the climatological normal $1971-2000$ varied between $21.3^{\circ} \mathrm{C}$ (July) and $4.4^{\circ} \mathrm{C}$ (January), with the average annual temperature of $12.3^{\circ} \mathrm{C}$. The average monthly precipitation varied between $18.4 \mathrm{~mm}$ (August) and $118.6 \mathrm{~mm}$ (December) with an annual total of $758.3 \mathrm{~mm}$. Climate records observed during the experimental period at the meteorological station of the Santa Apolónia farm, barely $200 \mathrm{~m}$ from the place where the experiments were conducted, are shown in Fig. 1.

The soil used in the pot experiment was collected in the plot where the field trial was carried out. Selected properties of a composite sample of that soil collected in the $0-20 \mathrm{~cm}$ layer are shown in Table 1.

\subsection{Experimental design and treatments characterization}

The field trial was organized in a completely randomized design with six fertilizer treatments and three replications. The fertilizer treatments consisted of three organic amendments, two enriched with beneficial microorganisms (BioF1, BioF2) and a composted and pelleted organic amendment not enriched (Organ), two treatments of a mineral fertilizer $\left[\mathrm{N}: \mathrm{P}\left(\mathrm{P}_{2} \mathrm{O}_{5}\right): \mathrm{K}\left(\mathrm{K}_{2} \mathrm{O}\right)\right.$ compound, 15:15:15] applied at a $\mathrm{N}$ rate equivalent to that of the organic amendments (MinR1) and at double the rate (MinR2), and a control treatment without $\mathrm{N}$ application. The control and the mineral fertilization treatments had the objective of creating an $\mathrm{N}$ response gradient to allow comparison of the performance of organic amendments. The organic and MinR1 treatments consisted of $40 \mathrm{~kg} \mathrm{Nha}^{-1}$ applied to each crop and the MinR2 treatment consisted of $80 \mathrm{~kg} \mathrm{~N}^{-1}$ per crop. Taking into account that the organic amendments were composed of different levels of $\mathrm{P}$ and $\mathrm{K}$, the rates of these nutrients were matched in all treatments with supplemental applications of superphosphate $\left(18 \% \mathrm{P}_{2} \mathrm{O}_{5}\right)$ and potassium chloride $\left(60 \% \mathrm{~K}_{2} \mathrm{O}\right)$. In lettuce, each experimental unit consisted of five rows of plants spaced at $50 \mathrm{~cm}$ (inter-row) and $30 \mathrm{~cm}$ (within row) with 12 plants in each row $(2.5 \times 3.6 \mathrm{~m})$. Each sample was composed of five random plants harvested inside the plots, excluding the plants of the external rows. In turnip, 10 lines spaced $25 \mathrm{~cm}$ apart were sown. The sample consisted of one linear meter of plants.

The pot experiment was also arranged in a completely randomized design with six fertilizer treatments as per the field trial, and with 10 replications (10 pots per treatment). Pots of $3 \mathrm{~L}$ in volume were used. The pots were filled with fine $(<2 \mathrm{~mm})$ and dried soil mixed with $50 \mathrm{~g}$ of perlite to favour aeration. The fertilizer rate was estimated in order for each pot to receive $0.375 \mathrm{~g} \mathrm{~N}_{\text {pot }}{ }^{-1}$. As in the field trial, the rates of $\mathrm{P}$ and $\mathrm{K}$ were adjusted with calcium superphosphate and potassium chloride. The $\mathrm{N}$ rate applied in the pot experiment was more conservative than that applied in the field to reduce a possible risk of a saline effect on plant growth. In the field, $40 \mathrm{~kg} \mathrm{~N} \mathrm{ha}^{-1}$ was used (except MinR2 treatment) and in the pots only the equivalent of $25 \mathrm{~kg} \mathrm{Nha}^{-1}$ was applied. This rate was estimated considering a planting density of 66,667 plants $\mathrm{ha}^{-1}$. In the pots there was also applied, at a rate of $0.08 \mathrm{~g} \mathrm{pot}^{-1}$, a commercial fertilizer formulation consisting of a mixture of macro- and micronutrients containing $10 \%$ $\mathrm{MgO}, 0.3 \% \mathrm{~B}, 18.5 \% \mathrm{SO}_{3}, 0.3 \% \mathrm{Cu}, 2 \% \mathrm{Fe}, 1 \% \mathrm{Mn}, 0.02 \% \mathrm{Mo}$, and $1.6 \% \mathrm{Zn}$. In the pot experiment, a single lettuce and six turnip plants were cultivated per pot.

The commercial organic amendments identified as BioF1 was prepared from sheep manure sterilized and enriched with Azotobacter $\left(8.6 \times 10^{7}\right.$ micro g $^{-1}$ soil $)$, and containing a total of $8.1 \times 10^{9}$ micro $^{-1}$ soil. The organic amendment identified as BioF2 was prepared from poultry manure sterilized and enriched with Azotobacter, and containing similar numbers of microorganisms than BioF1. The non-enriched organic amendment (Organ) is a municipal solid waste obtained from selective collection, composted and pelletized. Other characteristics of the three organic amendments are shown in Table 2.

\subsection{Installation and management of field and pot experiments}

The experiments were installed from the spring of 2014. The installation of the field trial was preceded by the preparation of the soil and the incorporation of the manures and fertilizers provided in the experimental design. Fertilizers and manures were incorporated into the $0-15 \mathrm{~cm}$ layer with a cultivator. Lettuces of cv. 'Maravilha-de-verão' (summer wonder) were obtained from a commercial nursery. At the time of transplantation, lettuces were in the phenological stage 2nd to 3rd true leaf unfolded, close to the end of the lag phase. As previously mentioned, plants were spaced at $50 \times 30 \mathrm{~cm}$. During the growing 


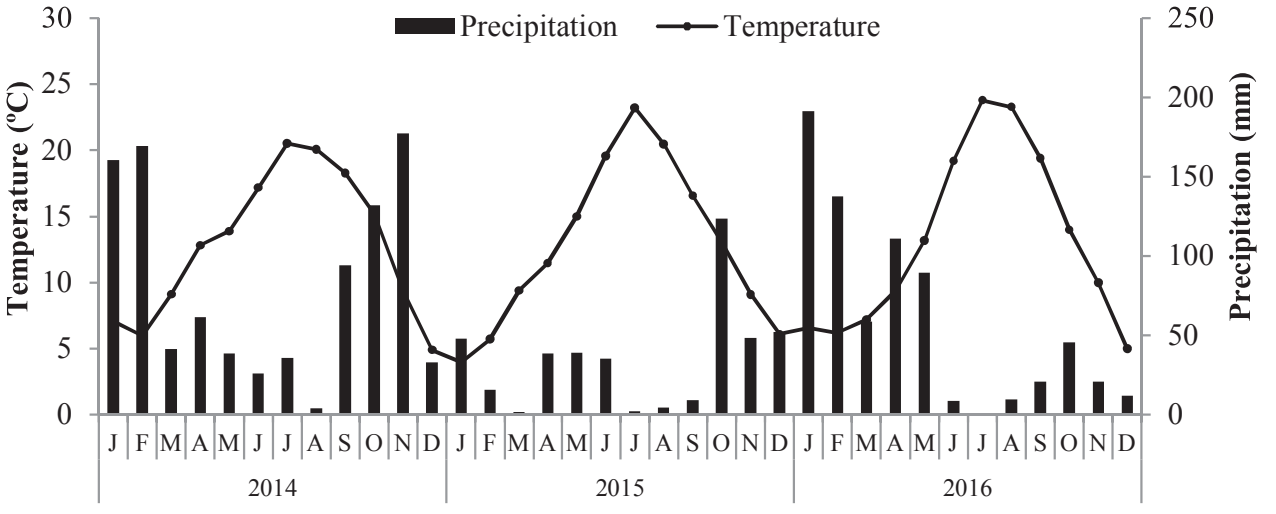

Fig. 1. Mean monthly temperatures and precipitations observed between 2014 and 2016 at the meteorological station of Santa Apolónia farm in Bragança, NE Portugal.
Table 1

Selected properties of the soil used in the field and pot experiments sampled shortly before the trials started at a depth of $0-20 \mathrm{~cm}$.

\begin{tabular}{llll}
\hline Soil properties & \multicolumn{3}{c}{ Soil properties } \\
\hline Clay (\%) & 23.9 & Extractable $\mathrm{P}\left(\mathrm{mg} \mathrm{P}_{2} \mathrm{O}_{5} \mathrm{~kg}^{-1}\right)^{\mathrm{d}}$ & 30.0 \\
Silt (\%) & 21.8 & Extractable $\mathrm{K}\left(\mathrm{mg} \mathrm{K}_{2} \mathrm{O} \mathrm{kg}^{-1}\right)^{\mathrm{d}}$ & 61.9 \\
Sand (\%) & 54.4 & Exchangeable bases & \\
$\mathrm{pH}_{\mathrm{H} 2 \mathrm{O}}$ & 6.3 & $\mathrm{Ca}\left(\mathrm{cmol}_{\mathrm{c}} \mathrm{kg}^{-1}\right)$ & 10.7 \\
$\mathrm{pH}_{\mathrm{KCl}}$ & 5.3 & $\mathrm{Mg}\left(\mathrm{cmol}_{\mathrm{c}} \mathrm{kg}^{-1}\right)$ & 3.6 \\
Oxidizable C $\left(\mathrm{g} \mathrm{kg}^{-1}\right)^{\mathrm{a}}$ & 8.5 & $\mathrm{~K}\left(\mathrm{cmol}_{\mathrm{c}} \mathrm{kg}^{-1}\right)$ & 0.3 \\
Total organic C $\left(\mathrm{g} \mathrm{kg}^{-1}\right)^{\mathrm{b}}$ & 18.4 & $\mathrm{Na}\left(\mathrm{cmol}_{\mathrm{c}} \mathrm{kg}^{-1}\right)$ & 0.4 \\
Extractable B $\left(\mathrm{mg} \mathrm{kg}^{-1}\right)^{\mathrm{c}}$ & 0.9 & Exchangeable acidity $\left(\mathrm{cmol}_{\mathrm{c}} \mathrm{kg}^{-1}\right)$ & 0.1 \\
\hline
\end{tabular}

a Walkley-Black.

b Incineration.

c Azomethine $\mathrm{H}$.

d Ammonium-lactate.

e Ammonium-acetate, $\mathrm{pH} 7$.

Table 2

Selected properties of the three organic amendments used in this study.

\begin{tabular}{llll}
\hline & BioF1 & BioF2 & Organ \\
\hline Moisture (\%) & 15.0 & 15.0 & 14.7 \\
Organic carbon $\left(\mathrm{g} \mathrm{kg}^{-1}\right)$ & 266.8 & 298.8 & 309.7 \\
$\mathrm{pH}\left(\mathrm{H}_{2} \mathrm{O}\right)$ & 7.0 & 7.0 & 8.4 \\
Conductivity $\left(\mathrm{mS} \mathrm{cm}^{-1}\right)$ & 8,7 & 6.5 & 3.3 \\
Total nitrogen $\left(\mathrm{g} \mathrm{kg}^{-1}\right)$ & 21.3 & 26.2 & 27.3 \\
$\mathrm{C} / \mathrm{N}$ ratio & 12.5 & 11.4 & 11.3 \\
Phosphorus $\left(\mathrm{g} \mathrm{P}_{2} \mathrm{O}_{5} \mathrm{~kg}^{-1}\right)$ & 25.5 & 30.0 & 12.2 \\
Potassium $\left(\mathrm{g} \mathrm{K}_{2} \mathrm{O} \mathrm{kg}^{-1}\right)$ & 17.0 & 30.0 & 19.0 \\
Calcium $\left(\mathrm{g} \mathrm{CaO} \mathrm{kg}^{-1}\right)$ & 76.5 & 42.0 & 78.2 \\
Magnesium $\left(\mathrm{g} \mathrm{MgO} \mathrm{kg}^{-1}\right)$ & 12.8 & 3.8 & 10.0 \\
\hline
\end{tabular}

season the plants were watered as needed to maintain normal growth through a drip irrigation system. In the growing cycle of turnip, sowing was performed after soil preparation and incorporation of fertilizers and manures. The growing season of turnip started after the first autumn rains which meant that an irrigation system was not required. During the growing season all crops were manually weeded by hoe. The dates of sowing of the six crops, lettuce - lettuce - turnip of 2014 and 2015, were, respectively, 30 April 2014, 30 June 2014, 11 September 2014, 24 April 2015, 25 June 2015, and 25 August 2015. The dates of harvest for the same growing cycles were, respectively, 26 June 2014, 10 September 2014, 7 November 2014, 23 June 2015, 21 August 2015, and 30 October 2015.

The pot experiments also began in the spring of 2014. The individual rates of the fertilizers and manures provided in the experimental design as well as the supplements to balance $P$ and $K$ rates among treatments were mixed in the soil with a bucket and a shovel. The fertilizer supplement with micronutrients was applied after installation of the crops with irrigation water. The origin, the cultivar and the phenological stage of the lettuces used in the pot experiment were the same as reported for the field trial. During the growing season the plants were watered as needed to maintain normal growth. Whenever weeds emerged they were manually removed. Turnip was installed by sowing 10-12 seeds per pot, being then hand-thinned to six plants per pot. The dates of sowing of the sequence of the six crops, lettuce lettuce - turnip of 2014 and 2015, were, respectively, 2 May 2014, 30 June 2014, 9 September 2014, 23 April 2015, 24 June 2015, and 25 August 2015. Harvest dates for the same crops were, respectively, 13 June 2014, 6 September 2014, 24 October 2014, 16 June 2015, 4 august 2015, and 12 October 2015.

\subsection{Assessment of soil $N$ availability}

In the pot experiments, soil nitrate levels were monitored during the growing seasons by using anion exchange membranes (AEM). Strips of $1 \times 2 \mathrm{~cm}$ of AEM were inserted 4-6 cm into the soil with a spatula and kept there for five days. The AEM were tied with a coloured line allowing for easy identification and removal from the soil. The AEM strips removed from soil were rinsed with distilled water and nitrate ions were then eluted in flasks containing $30 \mathrm{~mL} 0.5 \mathrm{~N}$ hydrochloric acid per AEM strip. The AEM strips were kept in the acid media for $75 \mathrm{~min}$. This analysis was performed on 31 May-5 June 2014, 22-27 September 2014, 16-21 July 2015, 1-6 October 2015, and 3-8 February 2016. This last date of insertion of AEM was carried out long after the last turnip growing cycle and had the objective of assessing the residual effect of the fertilizers and manures on soil $\mathrm{N}$ availability.

In March 2016 barley was grown without being fertilized with the same objective, evaluating the residual effect of the fertilizers and manures. The crop was sown on 9 March 2016 and cut on 18 May 2016. Twelve seeds per pot were sown, with the excess of young plants being hand-thinned to 8 plants per pot. Dry matter yield and $\mathrm{N}$ recovery in the above ground biomass were used as indicators of soil nitrogen availability.

\subsection{Laboratory analysis}

Nitrate concentrations in the AEM extracts were determined by UV-vis. spectrophotometry. The strips were regenerated in $0.5 \mathrm{M}$ $\mathrm{NaHCO}_{3}$ before being reused. All tissue samples (lettuce, turnip and barley) were oven dried at $70{ }^{\circ} \mathrm{C}$ and ground. Tissue analyses were performed by Kjeldahl $(\mathrm{N})$, colorimetry (B and $\mathrm{P}$ ), flame emission spectrometry $(\mathrm{K})$ and atomic absorption spectrophotometry $(\mathrm{Ca}, \mathrm{Mg}$, $\mathrm{Cu}, \mathrm{Fe}, \mathrm{Zn}$, and $\mathrm{Mn}$ ) methods.

\subsection{Data analysis}

Data analysis was carried out using JMP software. The comparisons of the effect of the fertilizer treatments were provided by ANOVA. After ANOVA examination, the means with significant differences $(\alpha=0.05)$ 


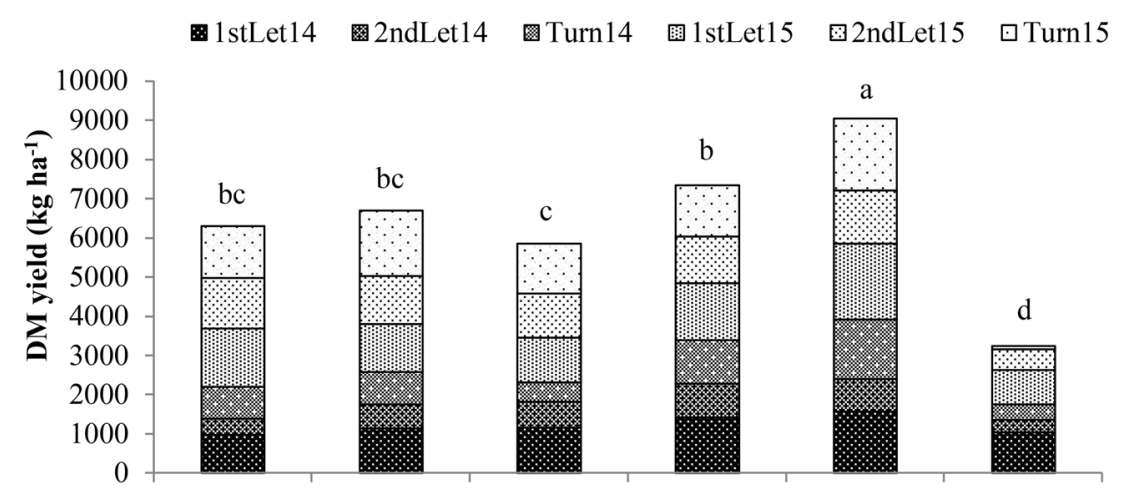

Fig. 2. Dry matter (DM) yield in the first (1st) and second (2nd) growing cycles of lettuce (Let) and turnip (Turn) in the field (above) and pot (below) experiments of 2014 (14) and 2015 (15) as a function of the fertilizer treatments. Letters above the columns is the result of Tukey HSD test $(\alpha=0.05)$ for the cumulative dry matter yield of the six harvests.

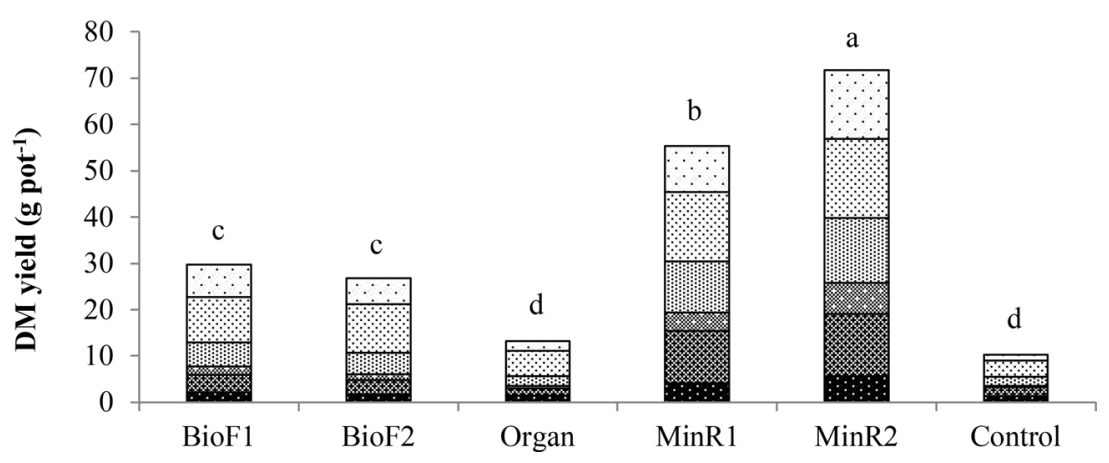

were separated by the Tukey HSD test. An index of $\mathrm{N}$ use efficiency (Apparent $\mathrm{N}$ Recovery, ANR) was also estimated according to the equation:

Apparent $\mathrm{N}$ Recovery $($ ANR, $\%)=100 \times(\mathrm{N}$ recovered in the fertilized treatments $-\mathrm{N}$ recovered in the control)/ $\mathrm{N}$ applied as a fertilizer.

\section{Results}

In the field trial, the highest and lowest mean dry matter yields from the six growing seasons were respectively found in MinR2 and control treatments (Fig. 2). The MinR1 treatment showed higher mean above ground DM yield than all the organic amendments but the differences were not statistically significant when compared to BioF1 and BioF2. The control treatment displayed significantly lower DM yields than any of the other treatments. In the pot experiment, the order of DM yields among treatments was practically the same but with more marked differences. The mineral fertilizers produced significantly more dry biomass than the organic amendments, even the MinR1 treatment. Among the organic amendments, Organ gave significantly lower DM yields than BioF2 and BioF1, with the results of Organ not being significantly different to those of the control treatment.

Nitrogen recovery in the above ground biomass of the six crops grown in the field as a function of the fertilizer treatment is presented in Fig. 3. Nitrogen recovery is the product of DM yield and N concentration in plant tissues. Since N concentration did not greatly change with the fertilizer treatments (data not shown), the pattern of results was quite similar to that of DM yield. However, the differences between fertilizer treatments were clearer. Nitrogen recovery in MinR1 was statistically different to those in BioF1 and Organ. Nitrogen recovery in above ground biomass in the pot experiment also showed a pattern similar to that was observed for DM yield but the differences among fertilizer treatments were higher. As observed for DM yield, organic amendments gave more modest results in the pots than in the field. Among organic amendments, BioF1 gave the higher results and Organ the lower, the latter not being statistically different to those of the control.

Phosphorus and $\mathrm{K}$ recoveries in pot and field experiments (Table 3) followed the patterns of dry matter yield (Fig. 2), since P and K concentration in plant tissues did not significantly vary among fertilizer treatments (data not shown). Therefore, the highest and the lowest values were respectively found in the MinR2 and the control treatments. A similar result of $\mathrm{P}$ and $\mathrm{K}$ was found for the recovery in plant tissues of $\mathrm{Ca}$ and $\mathrm{Mg}$ and the micronutrients that were analyzed (data not shown).

The use of AEM during the growing cycle generically showed that nitrate levels in the soil were higher in the fertilizer treatments in those producing more biomass and recovering more $\mathrm{N}$ in plant tissues (Table 4). However, 167 days after the last fertilizer application, in February 2016, nitrate levels in the soil reached, for the first time, the highest average value in an organic treatment (BioF1) in spite of the differences for the mineral treatments not being statistically significant.

Barley was grown in the pot experiment to assess the residual effect of six consecutive applications of the fertilizer treatments. The treatment MinR2 recorded the highest average $\mathrm{N}$ recovery (Fig. 4). However, MinR1, which received the same rate of $\mathrm{N}$ as the organic amendments, gave significantly lower $\mathrm{N}$ recovery than BioF1 and Biof2. The control, as expected, displayed the lower average values.

ANR from the field experiment greatly varied among the six growing cycles of lettuce and turnip. The lower values were associated with the organic amendments for which negative values (net immobilization) were often found, and the higher values were usually associated with the application of the mineral fertilizer at the lower rate, MinR1 (Table 5). In general terms, ANR increased in 2015 in comparison with the values found in 2014. When ANR was estimated for the total of the six crops, the higher value was associated with MinR1 (36.6\%) and the lower one to Organ (18.6\%). ANR found in the pot experiment showed a similar pattern to that observed in the field trial. The lower and the higher values were respectively found in Organ and MinR1 treatments. Total ANR for the six growing cycles varied from $2.4 \%$ (Organ) to $33.5 \%$ (MinR1).

Based on the field trial, the biofertilizers (BioF1 and BioF2) gave higher average $\mathrm{N}$ recoveries than Organ. From the difference of the 

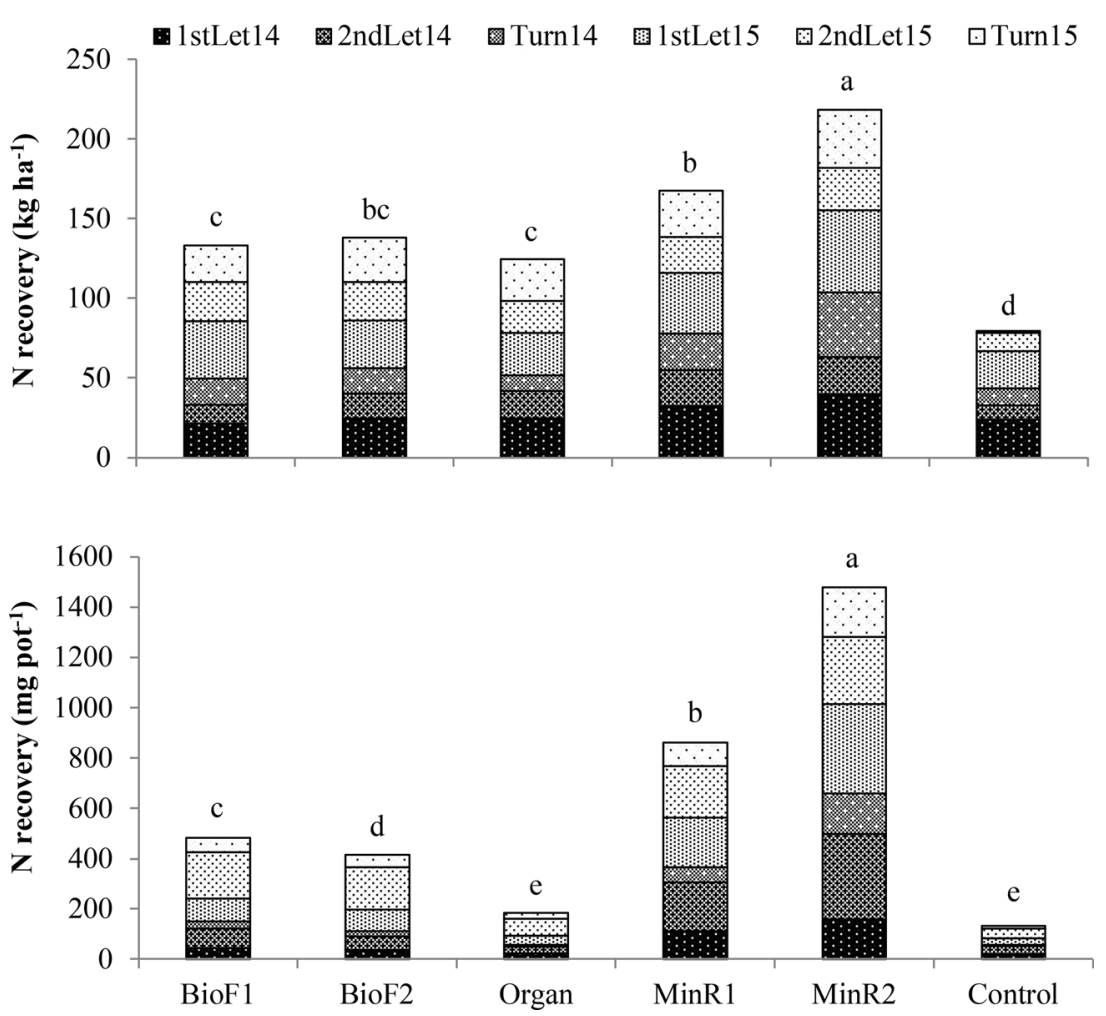

Fig. 3. Nitrogen recovery in the first (1st) and second (2nd) growing cycles of lettuce (Let) and turnip (Turn) in the field (above) and pot (below) experiments of 2014 (14) and 2015 (15) as a function of the fertilizer treatments. Letters above the columns is the result of Tukey HSD test ( $\alpha=0.05$ ) for the cumulative $\mathrm{N}$ recovery of the six harvests.
Table 3

Phosphorus and $\mathrm{K}$ recovery in the six crops grown in the field and pot experiments of 2014 and 2015 as a function of fertilizer treatments. In columns, means followed by the same letter are not significantly different by Tukey HSD test $(\alpha=0.05)$.

\begin{tabular}{llllll}
\hline & \multicolumn{3}{c}{ P recovery } & & \multicolumn{2}{l}{ K recovery } \\
\cline { 2 - 3 } \cline { 5 - 6 } & Field $\left(\mathrm{kg} \mathrm{ha}^{-1}\right)$ & Pot $\left(\mathrm{mg} \mathrm{pot}^{-1}\right)$ & & Field $\left(\mathrm{kg} \mathrm{ha}^{-1}\right)$ & Pot $\left(\mathrm{mg} \mathrm{pot}^{-1}\right)$ \\
\hline BioF1 & $23.0 \mathrm{bc}$ & $101.4 \mathrm{c}$ & & $184.1 \mathrm{bcd}$ & $1443.2 \mathrm{c}$ \\
BioF2 & $24.5 \mathrm{bc}$ & $85.5 \mathrm{~d}$ & & $199.5 \mathrm{bc}$ & $1375.0 \mathrm{c}$ \\
Organ & $20.8 \mathrm{c}$ & $44.3 \mathrm{e}$ & & $177.7 \mathrm{~cd}$ & $639.3 \mathrm{~d}$ \\
MinR1 & $28.1 \mathrm{~b}$ & $196.9 \mathrm{~b}$ & $241.1 \mathrm{~b}$ & $2181.5 \mathrm{~b}$ \\
MinR2 & $35.8 \mathrm{a}$ & $269.1 \mathrm{a}$ & $319.4 \mathrm{a}$ & $2924.4 \mathrm{a}$ \\
Control & $12.5 \mathrm{~d}$ & $37.7 \mathrm{e}$ & $128.1 \mathrm{~d}$ & $483.3 \mathrm{~d}$ \\
\hline
\end{tabular}

Table 4

Nitrate concentration in extracts of anion exchange membranes (AEM) inserted into the soil in the pot experiments as a function of the fertilizer treatments. In columns, means followed by the same letter are not significantly different by Tukey HSD test $(\alpha=0.05)$.

\begin{tabular}{llllll}
\hline $\begin{array}{l}\text { Fertilizer } \\
\text { treatment }\end{array}$ & $\begin{array}{l}\text { Jun } 2014 \\
29 \text { dalfa }^{\mathrm{a}} \\
\mathrm{mg} \mathrm{kg}^{-1}\end{array}$ & $\begin{array}{l}\text { Set } 2104 \\
18 \text { dalfa }\end{array}$ & $\begin{array}{l}\text { Jul } 2015 \\
27 \text { dalfa }\end{array}$ & $\begin{array}{l}\text { Out } 2015 \\
42 \text { dalfa }\end{array}$ & $\begin{array}{l}\text { Feb 2016 } \\
167 \text { dalfa }\end{array}$ \\
\hline BioF1 & $30.8 \mathrm{bc}$ & $67.2 \mathrm{bc}$ & $21.5 \mathrm{bc}$ & $8.7 \mathrm{ab}$ & $18.9 \mathrm{a}$ \\
BioF2 & $38.8 \mathrm{abc}$ & $43.2 \mathrm{~cd}$ & $23.6 \mathrm{bc}$ & $7.0 \mathrm{~b}$ & $16.7 \mathrm{ab}$ \\
Organ & $20.9 \mathrm{c}$ & $23.7 \mathrm{~d}$ & $19.3 \mathrm{~cd}$ & $6.6 \mathrm{~b}$ & $10.9 \mathrm{bc}$ \\
MinR1 & $50.3 \mathrm{a}$ & $89.6 \mathrm{~b}$ & $24.7 \mathrm{~b}$ & $7.7 \mathrm{~b}$ & $14.8 \mathrm{ab}$ \\
MinR2 & $44.1 \mathrm{ab}$ & $164.5 \mathrm{a}$ & $31.5 \mathrm{a}$ & $11.3 \mathrm{a}$ & $15.9 \mathrm{ab}$ \\
Control & $27.4 \mathrm{bc}$ & $62.4 \mathrm{bc}$ & $15.5 \mathrm{~d}$ & $5.3 \mathrm{~b}$ & $7.4 \mathrm{c}$ \\
\hline
\end{tabular}

a dalfa (days after the last fertilizer application).

average of the two biofertilizers to the Organ treatment, an estimate of $11.4 \mathrm{~kg} \mathrm{~N} \mathrm{ha}^{-1}$ was found (1.9 kg per crop). This value may represent supplemental biological $\mathrm{N}$ fixation due to the addition of microorganisms to BioF1 and BioF2.

The relationship between $\mathrm{N}$ recovery and above ground DM yield was linear with a very high coefficient of determination $\left(R^{2}=0.99\right)$ when established with the data of control and mineral fertilizer treatments (MinR1 and MinR2) (Fig. 5). All the organic amendments produced proportionally more dry biomass than the mineral fertilizer per unit of $\mathrm{N}$ recovery, since their results appeared positioned over the semi-straight line. The estimates of DM yields of the organic amendments over the mineral fertilizer averaged $720 \mathrm{~kg} \mathrm{ha}^{-1}$ for the six growing seasons ( $\sim 120 \mathrm{~kg}$ per crop).

\section{Discussion}

The mineral fertilizer applied at double the rate gave the highest DM yields. Between MinR1 and organic amendments, applied at the same $\mathrm{N}$ rate, the former gave higher $\mathrm{DM}$ yields and $\mathrm{N}$ recoveries. The organic amendments enriched with microorganisms produced more dry biomass and recovered more $\mathrm{N}$ than the non-enriched one, whereas the control treatment produced the lowest values. It is well-known that the organic amendments release their nutrients slowly, in the course of the mineralization-immobilization process. Previous researchers have tried to develop decay series for organic manures to forecast the annual rates of mineralization and help farmers to manage these resources (Pratt et al., 1976; Magdoff, 1978; Daudén et al., 2004; Mallory et al., 2010). Thus, the slow-release pattern of organic amendments is probably the main reason why they present lower performances in promoting crop growth in comparison with mineral fertilizers, as has been shown in previous studies (Mataruka et al., 1993; Fauci and Dick, 1994; Rodrigues et al., 2005, 2006).

Beegle et al. (2008) have also stressed that $\mathrm{N}$ recovery from manureamended plots is usually lower than recovery from plots amended with inorganic fertilizers due to the greater denitrification associated with manure-amended plots. In this experiment, ANR was lower in organic amendments in comparison to the mineral fertilizer and the values tended to increase from the first to the sixth growing cycle, stressing in this case the slow release nature of these materials. Low ANR from organic amendments is also a common result in experiments comparing mineral and organic sources of N (Beauchamp, 1987; Bitzer and Sims, 1988; Paul and Beauchamp, 1993; Rodrigues, 2004). However, the reduced ANR from organic manure is not necessarily an effective $\mathrm{N}$ loss; it might also be due to the possibility of more $\mathrm{N}$ being sequestered in the 


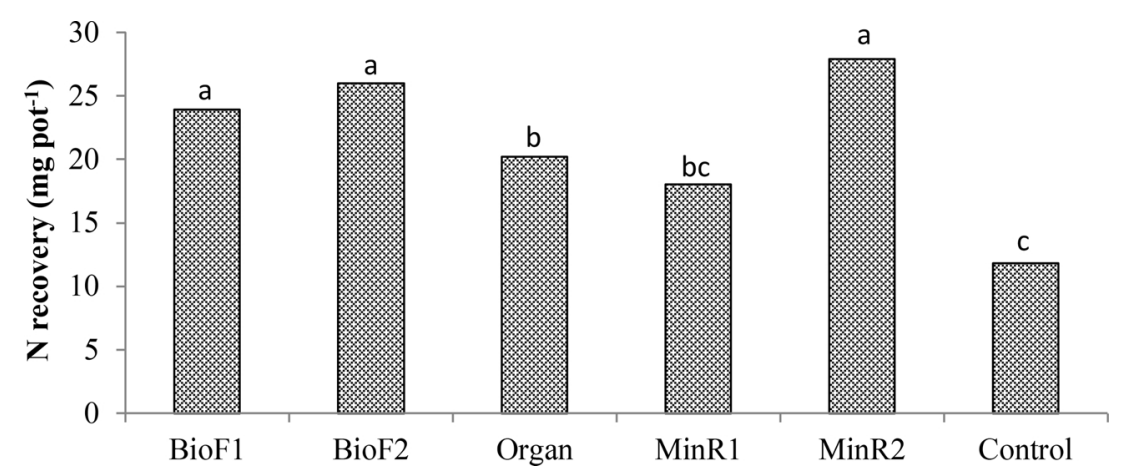

Table 5

Apparent $\mathrm{N}$ recovery (ANR) in the first (1st) and second (2nd) growing cycles of lettuce (Let) and in turnip (Turn) in the field and pot experiments of 2014 (14) and 2015 (15) as a function of the fertilizer treatments. ANR $=(\mathrm{N}$ recovery in fertilized plots $-\mathrm{N}$ recovery in control plots)/ $\mathrm{N}$ applied as a fertilizer $\mathrm{x} 100$.

\begin{tabular}{llllllll}
\hline $\begin{array}{l}\text { Fert. } \\
\text { treatment }\end{array}$ & 1stLet14 & 2ndLet14 & Turn14 & 1stLet15 & 2ndLet15 & Turn15 & Total \\
& $\%$ & & & & & & \\
\hline Field & & & & & & & \\
BioF1 & -5.8 & 7.0 & 14.0 & 32.3 & 32.8 & 53.5 & $\mathbf{2 2 . 3}$ \\
BioF2 & 2.1 & 16.1 & 13.6 & 16.6 & 31.3 & 66.7 & $\mathbf{2 4 . 4}$ \\
Organ & 2.6 & 20.3 & -3.0 & 9.4 & 20.8 & 61.7 & $\mathbf{1 8 . 6}$ \\
MinR1 & 22.0 & 33.8 & 29.7 & 37.3 & 28.1 & 68.6 & $\mathbf{3 6 . 6}$ \\
MinR2 & 20.2 & 17.9 & 36.7 & 36.0 & 18.7 & 43.7 & $\mathbf{2 8 . 9}$ \\
Pot & & & & & & & \\
BioF1 & 6.1 & 13.0 & 6.4 & 17.5 & 40.5 & 13.4 & $\mathbf{1 6 . 2}$ \\
BioF2 & 4.0 & 6.7 & 4.0 & 16.5 & 36.5 & 10.3 & $\mathbf{1 3 . 0}$ \\
Organ & 0.4 & -1.6 & 1.0 & 2.6 & 8.0 & 3.7 & $\mathbf{2 . 4}$ \\
MinR1 & 24.4 & 45.8 & 14.8 & 46.9 & 45.7 & 23.2 & $\mathbf{3 3 . 5}$ \\
MinR2 & 18.7 & 42.5 & 21.6 & 45.0 & 31.6 & 26.0 & $\mathbf{3 0 . 9}$ \\
\hline
\end{tabular}

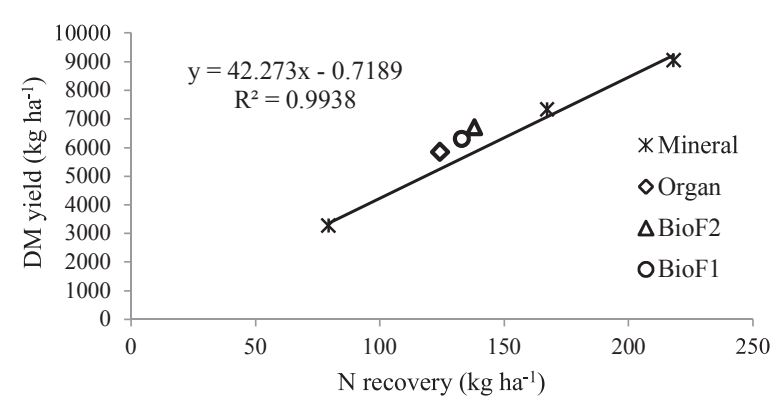

Fig. 5. Relationship between $\mathrm{N}$ recovery and dry matter (DM) yield from data of the six growing seasons of the field experiment. Linear adjustment was established from the results of the control and mineral fertilizer treatments (MinR1 and MinR2).

soil in an organic form (Kramer et al., 2002). In the pot experiment the general performance of the organic materials in the production of dry matter and $\mathrm{N}$ recovery was particularly low in comparison to the mineral fertilizer treatments. It is possible that the plastic plates that were placed at the base of the pots to avoid loss of water and nitrate leaching, could have created anoxic conditions after the irrigation events. Lack of oxygen in the soil and a fresh organic substrate are conditions particularly favourable to the activity of denitrifying bacteria (Coyne, 2008; Havlin et al., 2014), which may have caused substantial losses of $\mathrm{N}$ by denitrification.

The anion exchange membranes, by assessing the nitrate levels in the soil, corroborated the above-mentioned results, and proved to be itself a suitable method of monitoring soil nitrate levels as was shown in previous studies (Qian and Schoenau, 2007; Rodrigues et al., 2010; Arrobas et al., 2011; Arrobas and Rodrigues, 2013). Barley grown without fertilization showed a good performance of the organic
Fig. 4. Nitrogen recovery in barley grown in the pot experiment to evaluate the residual effect of the fertilizer treatments. Letters above the columns is the result of Tukey HSD test $(\alpha=0.05)$. amendments, with results of dry matter yield and $\mathrm{N}$ recovery higher than those of MinR1, proving that their fertilizing effect, though modest in the short-term, lasts longer.

The three organic amendments used in these experiments, excluding the microbial properties resulting from the enrichment in Azotobacter of two of them, were of similar composition and had very similar $\mathrm{C} / \mathrm{N}$ ratios (Table 2), which is usually referred to as one of the major factors determining the mineralization rate and the timing of $\mathrm{N}$ release (Beegle et al., 2008; Havlin et al., 2014). Among the three organic amendments, the non-enriched in Azotobacter consistently yielded the lower values of dry matter, $\mathrm{N}$ recovery and soil nitrate levels, although sometimes the differences were not statistically significant. Thus, it seems that the better performance of the amendments enriched with Azotobacter can be attributed to supplemental $\mathrm{N}$ fixation. On the basis of the average difference between $\mathrm{N}$ recovery in enriched with microorganisms and not enriched, an additional $\mathrm{N}$-fixing value of $11.4 \mathrm{~kg} \mathrm{ha}^{-1}$ during the six growing cycles of the field experiment was estimated (an average of $1.9 \mathrm{~kg} \mathrm{~N}$ per crop or $5.7 \mathrm{~kg} \mathrm{~N}$ per year).

The organic amendments produced more dry biomass than the mineral fertilizer per unit of $\mathrm{N}$ recovered. From this index, Organ produced a similar result to the organic amendment enriched in microorganisms. Thus, this result can be justified by a general manuring effect, consisting of the improvement of soil physical, chemical and biological properties, usually recognized in organic materials (Jenkinson, 1988; Weil and Magdoff, 2004). On average there was also observed an increase of $720 \mathrm{~kg} \mathrm{DM} \mathrm{ha}^{-1}$ in the six crops $(\sim 120 \mathrm{~kg}$ per crop) due to the manuring effect, and no relevant differences were found between micro-enriched and non-enriched manures. Thus, it seems from this experiment that no beneficial effects on crop growth could be attributed to the biofertilizers other than the increase in $\mathrm{N}$ fixation.

\section{Conclusions}

In the course of these experiments inorganic fertilizer gave higher $\mathrm{DM}$ yield and $\mathrm{N}$ recovery than the organic manures. However, the differences tended to decrease over time. A manuring effect was observed, associated with all organic fertilizers since they produce more biomass than the inorganic fertilizer per unit of $\mathrm{N}$ recovered. The biofertilizers recovered more $\mathrm{N}$ than the organic amendment not enriched with microorganisms, which was likely due to an increase in $\mathrm{N}$ fixation estimated at $5.7 \mathrm{~kg} \mathrm{yr}^{-1}$. No beneficial effects of biofertilizers on crop growth were found when compared with the manure not enriched, other than the increase in $\mathrm{N}$ fixation.

\section{Acknowledgements}

The authors are grateful to the Foundation for Science and Technology (FCT, Portugal) and FEDER under Programme PT2020 for financial support to CIMO (UID/AGR/00690/2013). 


\section{References}

Ansari, M.F., Tipre, D.R., Dave, S.R., 2015. Efficiency evaluation of commercial liquid biofertilizers for growth of Cicer aeritinum (chickpea) in pot and field study. Biocatal. Agric. Biotechnol. 4, 17-24.

Arrobas, M., Rodrigues, M.A., 2013. Agronomic evaluation of a fertiliser with D-CODER technology, a new mechanism for the slow release of nutrients. J. Agric. Sci. Technol. 15, 409-419.

Arrobas, M., Parada, M.J., Magalhães, P., Rodrigues, M.A., 2011. Nitrogen-use efficiency and economic efficiency of slow-release $\mathrm{N}$ fertilisers applied to irrigated turfs in a Mediterranean environment. Nutr. Cycl. Agroecosyst. 89, 329-339.

Aseri, G.K., Jain, N., Panwar, J., Rao, A.V., Meghwal, P.R., 2008. Biofertilizers improve plant growth, fruit yield, nutrition, metabolism and rhizosphere enzyme activities of Pomegranate (Punica granatum L.) in Indian Thar desert. Sci. Hort. 117, 130-135.

Banerjee, M.R., Yesmin, L., Vessey, J.K., 2009. Plant-growth-promoting Rhizobacteria as biofertilizers and biopesticides. In: Rai, M.K. (Ed.), Handbook of Microbial Biofetilizers. CRC Press, London, pp. 137-181.

Beauchamp, E.G., 1987. Corn response to residual $\mathrm{N}$ from urea and manures applied in previous years. Can. J. Soil Sci. 67, 931-942.

Beegle, D.B., Kelling, K.A., Schmitt, M.A., 2008. Nitrogen from animal manures. In: Schepers, J.S., Raun, W.R. (Eds.), Nitrogen in Agricultural Systems. Agronomy Monograph n 49. ASA, CSSA, SSSA, Madison, WI, USA pp. 823-881.

Bitzer, C.C., Sims, J.T., 1988. Estimating the availability of nitrogen in poultry manure through laboratory and field studies. J. Environ. Qual. 17, 47-54.

Cooper, J.E., Scherer, H.W., 2012. Nitrogen fixation. In: Marschner, P. (Ed.), Marschner's Mineral Nutrition of Higher Plants. Academic Press, UK, pp. 389-408.

Coyne, M.S., 2008. Biological denitrification. In: Schepers, J.S., Raun, W.R. (Eds.), Nitrogen in Agricultural Systems. Agronomy Monograph n ${ }^{\circ}$ 49. ASA, CSSA, SSSA, Madison, WI, USA pp. 201-253.

Daudén, A., Quílez, D., Martínez, C., 2004. Residual effects of pig slurry applied to a Mediterranean soil on yield and $\mathrm{N}$ uptake of a subsequent wheat crop. Soil Use Manage. 20, 156-162.

El-Sirafy, Z.M., Woodard, H.J., El-Norjar, E.M., 2006. Contribution of biofertilizers and fertilizer nitrogen to nutrient uptake and yield of Egyptian winter wheat. J. Plant Nutr. 29, 587-599.

Fauci, M.F., Dick, R.P., 1994. Plant response to organic amendments and decreasing inorganic nitrogen rates in soils from a long-term experiment. Soil Sci. Soc. Am. J. 58, 134-138.

Gentili, F., Jumpponen, A., 2009. Potential and possible uses of bacterial and fungal biofertilizers. In: Rai, M.K. (Ed.), Handbook of Microbial Biofetilizers. CRC Press, London, pp. 1-28.

Gupta, T.C., Aggarwal, S.K., 2008. Performance of wheat (Triticum aestivum) to incorporation of organic manure and bioinoculants. Arch. Agron. Soil Sci. 54, 615-627.

Havlin, J.L., Tisdale, S.L., Nelson, W.L., Beaton, J.D., 2014. Soil Fertility and Fertilizers, an Introduction to Nutrient Management, 8th ed. Pearson, Boston, USA.

Jahan, M., Mahallati, M.N., Amiri, M.B., Ehyay, H.R., 2013. Radiation absorption and use efficiency of sesame as affected by biofertilizers inoculation in a low input cropping system. Ind. Crops Prod. 43, 606-611.

Jenkinson, D.S., 1988. Soil organic matter and its dynamics. In: Wild, A. (Ed.), Russell's Soil Conditions \& Plant Growth, 11th ed. Longman Scientific \& Technical, New York pp 564-607.

Kramer, A.W., Doane, T.A., Horwath, W.R., van Kessel, C., 2002. Short-term nitrogen-15 recovery vs. long-term total soil $\mathrm{N}$ gains in conventional and alternative cropping systems. Soil Biol. Biochem. 34, 43-50.
Kumar, R., Bhatia, R., Kukreja, K., Behl, R.K., Dudeja, S.S., Narula, N., 2007. Establishment of Azotobacter on plant roots: chemotactic response, development and analysis of root exudates of cotton (Gossypium hirsutum L.) and wheat (Triticum aestivum L.). J. Basic Microbiol. 47, 436-439.

Kumar, S., Bauddh, K., Barman, S.C., Singh, R.P., 2014. Amendments of microbial biofertilizers and organic substances reduces requirement of urea and DAP with enhanced nutrient availability and productivity of wheat (Triticum aestivum L.). Ecol. Eng. 71, 432-437.

Kumar, M., Bauddh, K., Sainger, M., Sainger, P.A., Singh, R.P., 2015. Increase in growth, productivity and nutritional status of wheat (Triticum aestivum L.) and enrichment in soil microbial population applied with biofertilizers entrapped with organic matrix. J. Plant Nutr. 38, 260-276.

Magdoff, F.R., 1978. Influence of manure application rates and continuous corn on soil-N. Agron. J. 70, 629-632.

Mallory, E.B., Griffin, T.S., Porter, G.A., 2010. Seasonal nitrogen availability from current and past applications of manure. Nutr. Cycl. Agroecosyst. 88, 351-360.

Mataruka, D.F., Cox, W.J., Pleasant, J.M., van Es, H.M., Klausner, S.D., Zobel, R.W., 1993. Tillage and nitrogen source effects on growth yield, and quality of forage maize. Crop Sci. 33, 1316-1321.

Nuruzzaman, M., Ashrafuzzaman, M., Islam, M.Z., Islam, M.R., 2003. Field efficiency of biofertilizers on the growth of okra (Abelmoschus esculentus [(L.) Moench]). J. Plan Nutr. Soil Sci. 166, 764-770.

Paul, J.W., Beauchamp, E.G., 1993. Nitrogen availability for corn in soils amended with urea, cattle slurry, and composted manures. Can. J. Soil Sci. 73, 253-266.

Pratt, P.F., Davis, S., Sharpless, R.G., 1976. A four-year trial with animal manures. I. Nitrogen balances and yields. Hilgardia 44, 99-112.

Qian, P., Schoenau, J.J., 2007. Using an anion exchange membranes to predict soil available $\mathrm{N}$ and $\mathrm{S}$ supplies and the impact of $\mathrm{N}$ and $\mathrm{S}$ fertilization on canola and wheat growth. Pedosphere 17, 77-83.

Rodrigues, M.A., Coutinho, J., Martins, J., Arrobas, M., 2005. Quantitative sidedress nitrogen recommendations for potatoes based upon crop nutritional indices. Eur. J. Agron. 23, 79-88.

Rodrigues, M.A., Pereira, A., Cabanas, J.E., Dias, L., Pires, J., Arrobas, M., 2006. Crops use-efficiency of nitrogen from manures permitted in organic farming. Eur. J. Agron. 25, 328-335.

Rodrigues, M.A., Santos, H., Ruivo, S., Arrobas, M., 2010. Slowrelease N fertilisers are not an alternative to urea form fertilisation of autumn-grown tall cabbage. Eur. J. Agron. 32, 137-143.

Rodrigues, M.A., 2004. Establishment of continuous critical levels for indices of plant and pre-sidedress soil N status in the potato crop. Commun. Soil Sci. Plant Anal. 35 2067-2085.

Russelle, M.P., 2008. Biological dinitrogen fixation in agriculture. In: Schepers, J.S., Raun, W.R. (Eds.), Nitrogen in Agricultural Systems. Agronomy Monograph n49. ASA, CSSA, SSSA, Madison, WI, USA pp. 281-359.

Sharma, A.K., 2005. Biofertilizers for Sustainable Agriculture. Agrobios (India), Jodhpur, India.

Singh, N.K., Chaudhary, F.K., Patel, D.B., 2013. Effectiveness of Azotobacter bio-inoculant for wheat grown under dryland conditions. J. Environ. Biol. 34, 927-932.

Smil, V., 2001. Enriching the Earth: Fritz Haber, Carl Bosch, and the Transformation of World Food Production. Massachusetts Institute of Technology, Massachusettes, USA.

Weil, R.R., Magdoff, F., 2004. Significance of soil organic matter to soil quality and health. In: Magdoff, F., Weil, R.R. (Eds.), Soil Organic Matter in Sustainable Agriculture. CRC Press, Boca Raton, Florida, USA, pp. 1-43. 